Williams, M. A. (1958). J. gen. Microbiol. 21, 109-123

\title{
Chromatin Patterns in Spirillum anulus
}

\author{
By MARION A. WILLIAMS* \\ Department of Bacteriology, University of Southern California, \\ Los Angeles, California, U.S.A.
}

SUMMARY: The chromatin configurations of acid-Giemsa preparations of Spirillum anulus were followed sequentially, at $2 \mathrm{hr}$. intervals, for $48 \mathrm{hr}$. A series of broth cultures were inoculated with $0.1 \mathrm{ml}$. of a 7 -day broth culture, incubated at $30^{\circ}$ and centrifuged at $2 \mathrm{hr}$. intervals. The sedimented cells were used to inoculate agar plates for use in making smears by the agar block method. The smears were fixed in acid-alcohol, hydrolysed in N-HCl solution at $60^{\circ}$ for 8 or $15 \mathrm{~min}$. and stained with Giemsa. Samples of living cells, taken from the sedimented cells at all time intervals, were examined by phase-contrast and darkfield microscopy.

The majority of the early cells $(0-16 \mathrm{hr}$.) were resistant to acid hydrolysis, being undifferentiated by $15 \mathrm{~min}$. of hydrolysis until the 12th $\mathrm{hr}$. of growth. After the $16 \mathrm{th} \mathrm{hr}$. of the growth cycle the cells showed an abrupt change in their reaction toward acid hydrolysis; subsequent preparations were hydrolysed for $8 \mathrm{~min}$. The early cells appeared undifferentiated by phase contrast until approximately the 14th $\mathrm{hr}$. of growth; after this time inclusions could be observed in the cells. Transparent cells containing dark inclusions were observed in the living cells by the $16 \mathrm{hr}$. of growth and coincided with the abrupt change of the acid-Giemsa cells toward acid hydrolysis.

The pattern of the chromatin configurations found in the acid-Giemsa cells consisted in : (1) an axial filament which fragmented into thick bars, from which spherical bodies were formed; (2) the direct division of the spherical bodies into smaller spheres, from which bead-like granules were formed by means of intermediate $\mathrm{X}$-, $\mathrm{Y}$-, and V-forms or the direct formation of rings of bead-like granules from the spherical bodies; (3) the re-formation of the axial filaments from the bead-like granules with the aggregation of all the chromatin material of the cell at the centre of the cells; (4) the division of the aggregated chromatin material on cell division and the extension of the chromatin material in the form of an axial filament; and (5) the re-formation of the spherical bodies and bead-like granules as outlined in steps (1) and (2) from the axial filaments.

Essentially the same types of chromatin configurations were observed in living cells. The most exact correlation between the living and fixed images of the chromatin bodies of Spirillum anulus occurred between the 18th and 30th $\mathrm{hr}$. of the growth cycle. The correlation between the living and fixed images of the chromatin bodies of $S$. anulus was less exact at other time intervals. Various theories concerned with the occurrence of axial filaments and chromatin aggregations in bacterial cells are discussed.

Robinow $(1956 a, b)$ has pointed out that much of the confusion which has arisen in the interpretation of chromatin bodies of bacteria is due to the use of bacterial cells of differing ages of growth. He has called attention to the fact that the 'nucleoids and chromatinic dumb-bell bodies', shown in bacterial cells by certain cytologists (Badian, 1933; Stille, 1937; Robinow, 1944), were demonstrated in cells from 'very young growing cultures' whereas the chromidial nuclei and axial filaments of the older school of bacterial cytologists

* Present address: The Biological Laboratories, Harvard University, Cambridge 38, Mass. U.S.A. 
(Guilliermond, 1908; Dobell, 1911; Delaporte, 1939, 1950) were found in cells from older cultures.

Robinow (1956b) has also called attention to the discrepancy between the living and fixed images of the chromatin bodies of bacterial cells. Studies of direct observation of the chromatin bodies of living cells have been made by a number of investigators, among whom are Stempen (1950), Clifton \& Ehrhard (1952), and Mason \& Powelson (1956). With the exception of the article by Mason \& Powelson (1956) the information to be gained about the morphology and division of the chromatin bodies of living bacterial cells has been rather meagre, consisting mainly in the information that the light areas, as observed by phase contrast, are correlated with the position of the chromatin bodies in fixed, hydrolysed and stained cells. Mason \& Powelson (1956) were able to correlate karyokinesis with cytokinesis in living cells of Escherichia coli, but their findings in Bacillus cereus were less conclusive.

The chromatin bodies of Spirillum anulus have been followed in acidGiemsa and living cells from resting stage (non-dividing cells) to resting stage in an attempt to resolve some of the problems of the chromatin bodies of bacteria, as pointed out by Robinow $(1956 a, b)$.

\section{METHODS}

Cultural methods. Spirillum anulus was grown in broth of the following composition: peptone, 5.0 g.; beef extract, 3.0 g.; yeast autolysate, $3.0 \mathrm{~g}$.; distilled water, 11 . A solid medium was prepared by adding $16.5 \mathrm{~g}$. agar/l. to the above formula. To insure a plentiful supply of resting cells (non-dividing cells), 3 broth tubes were inoculated with $0.1 \mathrm{ml}$. of sedimented cells of $S$. anulus on each of 7 days prior to the beginning of the experimental procedures. A series of broth tubes was inoculated with $0.1 \mathrm{ml}$. of a 7-day broth culture, using 6 broth tubes at each time interval. The times of inoculation were varied so that cells in consecutive stages of growth could be obtained during one working day. The subcultures were incubated at $30^{\circ}$ and centrifuged $2 \mathrm{hr}$. before use. The supernatant fluid was discarded by decanting and the tubes shaken vigorously to redistribute the cells in the small amount of fluid left (c. $0 \cdot 2 \mathrm{ml}$.). A sample was removed, at each time interval, from the sedimented cells for the examination of living cells by phase contrast and darkfield microscopy. Three agar plates were inoculated with $0.1 \mathrm{ml}$. of the sedimented cells at $2 \mathrm{hr}$. intervals. The plates were incubated at $30^{\circ}$ for at least $2 \mathrm{hr}$. before use; they were not used after $6 \mathrm{hr}$. incubation.

Fixed cells. Impression smears were made by the agar block method on glass slides, 6 slides being made at each time interval. The smears were allowed to come just to dryness and placed in acid-alcohol fixative ( 1 part glacial acetic acid to 3 parts ethanol) for $10 \mathrm{~min}$. The fixed smears were passed through a graded series of ethanol and distilled water to distilled water and hydrolysed in $\mathrm{N}-\mathrm{HCl}$ solution at $60^{\circ}$. Early cells (0-16 hr.) were hydrolysed for $15 \mathrm{~min}$; s subsequent preparations were hydrolysed for $8 \mathrm{~min}$. After hydrolysis the smears were rinsed in distilled water and stained in Giemsa solution, $\mathrm{pH} \mathbf{7 \cdot 0}$, for $\mathbf{3 0} \mathrm{min}$. 
Living cells. At each $2 \mathrm{hr}$. interval, one drop of the sample of the living cells was placed in a drop of broth on a sterile glass slide, covered with a sterile no. 0 coverslip and excess fluid was removed with filter-paper. The preparations were ringed with immersion oil to prevent drying and observed by phasecontrast and darkfield microscopy.

Photography. The stained smears were examined with the Leitz Ortholux microscope, equipped with an achromatic condenser, an apochromatic objective $(\times 90)$, N.A. 1.25 and examined with compensating oculars $(\times 12)$. The photographs were made with the Leitz Aristophot camera using Panatomic $\mathrm{X}$ sheet film and a $560 \mathrm{~m} \mu$ interference filter.

Observations and photographs of living cells were made with the phase attachment of the Leitz Ortholux microscope which permits a continuous transition from 'brightfield' to 'phase contrast' to 'darkfield' by the adjustment of the height of the mirror body in the condenser. An apochromatic oilimmersion phase-contrast objective $(\times 90)$ N.A. $1 \cdot 10$ and compensating oculars $(\times 12)$ were used for photographs and observations. The photographs were made with the Leitz Makam camera, using Royal Pan sheet film and employing the green filter supplied with the Leitz phase equipment.

\section{RESULTS}

There were two reasons for the use of $S$ pirillum anulus as the experimental organism, the more important of these being the slow growth rate which permitted the comparison of the chromatin configurations of acid-Giemsa cells with those of the living cells of the same age. The large size of the cells which provided chromatin configurations of considerable size was of secondary importance.

Although the cells of Spirillum anulus were followed for a 7-day period (the time necessary to proceed from resting cells to resting cells), the results reported are those found for the first $48 \mathrm{hr}$. only. The essential pattern of the chromatin configurations was established within this time limit, and the configurations observed on the 3rd and 4th days of the growth cycle were essentially the same as those to be reported for the 2nd day. All types of chromatin configurations were found by the 5th day of growth, and by the 6 th day the cells showed only sporadic division. The cells were in the resting phase of the growth cycle by the 7th day.

Previous investigations of the species of Spirillum (Williams, 1955; Williams \& Rittenberg, 1957) have shown that the chromatin configurations of acidGiemsa cells are contained within or associated with the large inclusions of the cells. The large inclusions, however, show staining reactions considered to be diagnostic of volutin by Grimme (1902). Despite this fact, data will be presented to show that the inclusions of the living cells may be considered to be the equivalent of the chromatin bodies of the acid-Giemsa cells. Although the large inclusions of the unhydrolysed cells of Spirillum anulus show staining reactions of volutin, this is not true for the small inclusions.

No effort was made to obtain synchronized cultures of Spirillum anulus. 
A heterogeneous population was observed in the very early cultures $(0-10 \mathrm{hr}$.), as well as in cultures after the 5 th day of the growth cycle. Between the 16th and $48 \mathrm{th} \mathrm{hr}$. of growth, the cells showed essentially the same type of inclusion in the living cells, at a particular time interval, and the chromatin configurations found in acid-Giemsa cells, at a particular time interval, were similar.

Dividing cells were not observed in the living cells prior to the 6th $\mathrm{hr}$. of growth and then cell division was observed only sporadically. After the 14th hr. of growth, the number of dividing cells increased but was still small. The greatest proportion of dividing cells was observed between the 30th and 48th hr., at which time approximately $50 \%$ of the cells were either dividing or showed evidence of recent cell division. The criterion of cell division was constriction and fission; that of recently divided cells was the short $\frac{1}{2}$ to $1 \frac{1}{2}$ curved forms shown in Pl. 1, figs. 6-9. The correlation between karyokinesis and cytokinesis, found by Mason \& Powelson (1956) for living cells of Escherichia coli was anticipated but not observed. The chromatin bodies of living cells of Spirillum anulus, as observed by phase-contrast or darkfield microscopy, resembled the forms shown by Mason \& Powelson (1956) for Bacillus cereus rather than those of $\boldsymbol{E}$. coli.

The data reported for living and fixed cells of Spirillum anulus are divided into three sections : (1) early cells (0-16 hr.) in which cell division was observed to occur only sporadically; (2) young cells (16-30 hr.) in which cell division occurred in an increasing number of the cells; and (3) mature cells (30-48 hr.) during which time the greatest proportion of dividing cells was observed.

\section{Early cells (0-16 hr.)}

Acid-Giemsa cells. The appearance of approximately $90 \%$ of the cells, prior to the $12 \mathrm{th} \mathrm{hr}$. of growth, was undifferentiated (Pl. 1, figs. 1-3). These cells were extremely resistant to acid hydrolysis, appearing undifferentiated even when hydrolysed for $30 \mathrm{~min}$. Since the prolonged hydrolysis time did not reveal discrete chromatin bodies within the cells, a $15 \mathrm{~min}$. period of hydrolysis was used for such preparations. The reaction of the cells toward acid hydrolysis changed abruptly after the 16th hr. of growth and subsequent preparations were hydrolysed for 8 min only.

The chromatin material of the cells of Spirillum anulus could be differentiated from the intensely stained cytoplasm by the 12th hr. (Pl. 1, fig. 10). At this time the chromatin material appeared as an axial filament which fragmented into thick bars by the 14th hr. of growth (Pl. 1, fig. 11). Spherical chromatin bodies were formed from the bars (Pl. 1, fig. 12) by the 16th hr. These spherical bodies either divided directly (Pl. 1, fig. 14) or formed curved bar-like structures (Pl. 1, fig. 13).

Living cells. The majority of the living cells appeared undifferentiated until the 14th hr. of growth (Pl. 1, figs. 4-5). A few of the cells (approximately $10 \%$ ) contained large inclusions which subsequent observations showed to be similar to those observed in living cells on the 4th and 5th days of the growth cycle. Since no effort was made to obtain synchronized cultures, a heterogeneous population was not unexpected. The visual appearance of the early cells, by 
phase contrast, was that of purplish cells as noted by Clifton \& Ehrhard (1952) for cells of Bacillus anthracis.

Inclusions could be observed in a small percentage of the cells by the 14th hr. (Pl. 1, fig. 15), but the majority of the cells remained undifferentiated (Pl. 1, fig. 9). The number of the inclusions in the cells increased by the 16th hr. but it was difficult to differentiate the periphery of the inclusions from the dark cytoplasm in phase-contrast observations (Pl. 1, fig. 16a), the inclusions appeared as bright purplish bodies in a dull purple cytoplasm and they photographed as empty spaces in the phase-contrast photographs (Pl. 1, fig. 16a). Darkfield observations and photographs, however, showed the spherical shape of the inclusions (Pl. 1, fig. 16b).

Young cells (16-30 hr.)

Acid-Giemsa cells. The changes in the chromatin configurations of the cells of Spirillum anulus occurred more rapidly after the 16th hr. of the growth cycle. Between the 18th and 20th hr. the chromatin bodies appeared as transverse bar-like structures (Pl. 2, figs. 19-20). By the 22nd hr. solid or broken ring-like structures, surrounding an achromatic core, appeared within the cells (Pl. 2, fig. 21), but these forms were observed with greater frequency by the 24th hr. (Pl. 2, fig. 22). Both types of configurations were often observed within the same cell (Pl. 2, fig. 23). The ring-like structures appeared to break up into smaller bodies and form small bead-like granules by means of intermediate X-, Y- and V-forms (Pl. 2, figs. 21-23). The bead-like granules predominated in the cells by the 24th hr. of growth, either as discrete bodies or as rings or bars of interconnected granules (PI. 2, figs. 22, 30). Various arrangements of the bead-like chromatin granules were observed in the cells until approximately the 30th hr. of growth.

Living cells. The cytoplasm of the cells became increasingly lighter after the 16th $\mathrm{hr}$. of growth and the inclusions could be observed with greater accuracy (Pl. 1, figs. 17, 18). By the 20th hr. the majority of the cells appeared transparent with dark purple inclusions (Pl. 2, figs. 27, 29, 31-35). The appearance of the transparent cells in the cultures of Spirillum anulus coincided with the change in the reaction of the fixed cells toward acid hydrolysis. Transparent cells were the only ones observed between the 20th and 24th $\mathrm{hr}$. of the growth cycle. Transparent cells were observed by Clifton \& Ehrhard (1952) in phasecontrast observations of living cells of Bacillus anthracis, but these authors considered such cells to be non-viable. The transparent cells of Spirillum anulus, however, were viable and growth and cell division occurred normally in such cells (Pl. 2, fig. 27). The cytoplasm of a few cells had resumed the dark appearance by the 24th hr. and was dark in the majority by the $30 \mathrm{th} \mathrm{hr}$.

The morphology of the inclusions during the transparent phase of the cells was varied. Both large and small inclusions (Pl. 2, figs. 24b, 31) were common between the 18th and $20 \mathrm{th} \mathrm{hr}$., although the transverse bar-like forms were also observed at this time (Pl. 2, fig. 25 b). The predominating form of the inclusions after the 24th hr. was either the bead-like granule or ring forms (Pl. 2, figs. 27, 29, 34 and 35). The bead-like granules occurred either as discrete 
bodies (Pl. 2, fig. 35) or in the form of rings of bead-like granules (PI. 2, fig. 29). The most exact correlation between the living and fixed images of the chromatin bodies of Spirillum anulus occurred during the transparent phase. Chromatin configurations which have a similar form in both living and acid-Giemsa cells are shown in pairs of photographs in Pl. 2, figs. 24 and 25. In these photographs, the acid-Giemsa cells are denoted by the letter ' $a$ ', the living cells by the letter ' $b$ '. In figs. 24 $a, b$ the chromatin bodies are seen as spheres; in figs. $25 a, b$ as chromatin bars. The apparent similarity between the ringlike bodies of the cells shown in Pl. 2, figs. 26a,b is a photographic illusion since the large inclusions of the living cell in fig. $26 b$ had the appearance, visually, of spherical bodies consisting of a ring of dark material surrounding a brightly refractile centre. The photographic appearance of these large inclusions as rings of dark material enclosing an empty space is most probably due to the inability of black and white film to discern both colour and brightness, since such film records brightness alone (Miller \& Brumitt, 1945).

Murray (1953), who also noted differences in the appearance of living and fixed chromatin bodies in bacteria, attributed these differences to the type of fixation. To determine if fixation in acid-alcohol was a source of the discrepancy between the visual appearance of these inclusions and their actual appearance in acid-Giemsa preparations, comparisons were made of the same cells in the living conditions and as fixed cells. Living cells from a $24 \mathrm{hr}$. culture are shown in Pl. 2, fig. 27, in which the large inclusions are shown in the dividing cells at the top of the photograph. In preparations fixed in acidalcohol, however, these inclusions had the appearance of dull white, fibrous spherical bodies without the refractile centre observed in the visual observations of living cells by phase contrast. Cells from the same preparation, when fixed in acid-alcohol and stained with Giemsa for photographic purposes, are shown in $\mathrm{Pl}$. 2, fig. 28. In this photograph, the large spherical inclusions which photograph as ring-like bodies (Pl. 2, fig. 27), can be seen to have a spherical form (Pl. 2, fig. 28, upper cells, marked with an arrow). Similar preparations, when fixed and hydrolysed and stained with Giemsa, showed these inclusions as ring-like structures (Pl. 2, fig. 26a).

No discrepancy was observed in the visual appearance of either the small spherical inclusions or the bead-like granules in any type of observation. Their morphology was essentially the same in visual observations; in their photographic appearance (Pl. 2, figs. 24 b, 27, lower cells); in the fixed but unhydrolysed Giemsa-stained preparations (PI. 2, fig. 28, lower cells); and in acidGiemsa preparations (Pl. 2, figs. 24, $a, 30)$.

Robinow (1956a) has described similar ring-forms in acid-Giemsa preparations of Bacillus megaterium and $\boldsymbol{B}$. cereus, as follows:

'... Recently divided ('resting') chromatin bodies in Giemsa preparations appear to consist only of chromatin matter, but division figures frequently appear to enclose a core of non-chromatinic matter more refractile than ordinary cytoplasm. The sudden emergence of this material during division makes one wonder whether it is not in the chromatin bodies at all times but usually invisible because we see them mostly in profile. The non-chromatinic centre 
of the "small $c$ "-type of "resting" chromatin body, mentioned above, may well be the origin of the "core" in division figures."

Robinow (1956a) considered the ring-like forms as division figures and this concept appears applicable to some of the division forms observed in living cells of Spirillum anulus. These forms were carefully observed during the transparent phase of the cells when they could be well differentiated from the cytoplasm. The division processes apparently consisted of two types, neither of which occurred in a clear-cut manner. One type consisted of the division of spherical inclusions (Pl. 2, fig. 31) into two smaller spherical bodies (Pl. 2, fig. 32, upper inclusion). The separation of the two halves, however, was never observed; instead these two bodies appeared to subdivide further (Pl. 2, fig. 32 (lower inclusions)), forming a semicircular body (Pl. 2, fig. 33). The semicircular bodies either formed the bead-like granules directly (Pl. 2, fig. 34) as $V$-shaped interconnected granules or the bead-like granules were given off from the semicircular forms by a process resembling budding (Pl. 2, fig. 34, inclusions indicated by an arrow). The other type of the formation of the bead-like granules from the large spherical bodies was by the direct formation of rings of the bead-like granules (Pl. 2, fig. 29, indicated by an arrow). The predominating form of the inclusions in the living cells between the 24th and $29 \mathrm{th} \mathrm{hr}$. of the growth cycle was that of the bead-like granule.

\section{Mature cells (30-48 hr.)}

Acid-Giemsa cells. By the 30th hr. of growth, the bead-like granules began to coalesce in the cells ( $\mathrm{Pl} .3$, fig. 36) and, by the $32 \mathrm{nd} \mathrm{hr}$. the chromatin material appeared around the edge of the vacuoles (Pl. 3, fig. 37). Thick rings of chromatin material were observed in the cells by the 34th hr. (Pl. 3, fig. 38) with the condensation of the chromatin material at the centre of the cells by the $36 \mathrm{th} h \mathrm{~h}$. (Pl. 3, fig. 39). By the $40 \mathrm{th} \mathrm{hr}$. of growth all the chromatin material was aggregated into a solidly staining mass at the centre of the cells ( $\mathrm{Pl} .3$, figs. 40, 41) which divided on cell division (Pl. 3, figs. 42, 43). After cell division the compact mass of chromatin material was redistributed in the cells, along the vacuoles, in the form of an axial filament (PI. 3, fig. 44). This separated into the curved bars and small spherical bodies (Pl. 3, fig. 45) in a manner similar to that shown in the early cells (Pl. 1, figs. 13, 14) or divided into the small spherical bodies directly ( $\mathrm{Pl}$. 3, fig. 46). By the 48 th hr. of the growth cycle, the predominating form of the chromatin material in the cells was again the small bead-like granule (Pl. 3, fig. 48).

The chromatin configurations, found in the cells of Spirillum anulus between the 24th and 48 th $\mathrm{hr}$. of the growth cycle, were repeated, in a cyclical manner, for the succeeding 2 days (3rd and 4th days) of the growth cycle. By the 5th day all types of chromatin configurations were observed with the type shown in $\mathrm{Pl}$. 3, fig. 38, predominating. By the 6th day the undifferentiated cell similar to those of the early cells (Pl. 1, figs. 1-10) were observed, and by the 7 th day the undifferentiated cells predominated.

The essential pattern of the chromatin configurations in acid-Giemsa cells of Spirillum anulus appears to consist in: (1) the formation of an axial 
filament, which fragments into bars from which spherical bodies are derived; (2) the division of the spherical bodies into transverse bars and bead-like granules; (3) the condensation of the bead-like granules with the re-formation of the axial filament along the vacuoles of the cells; (4) the aggregation of all the chromatin material of the cells at the centre in a solid staining mass; (5) the division of the solidly staining mass on cell division; and (6) the redistribution of the chromatin material in the form of an axial filament from which the bead-like granules are again re-formed. The times at which these various forms are found in the cells appears to be correlated with the age of the cells rather than with cell division.

Living cells. Observations of living cells by either phase-contrast or darkfield microscopy became increasingly difficult after the 30th hr. of the growth cycle. The dark appearance of the cytoplasm made it difficult to differentiate the periphery of the inclusions by phase contrast and the bright glare from the centre of the inclusions made darkfield observations practically impossible. A few cells could be observed clearly, at each time interval, and these appeared to be representative of the majority of the cells.

The number of inclusions was greatly increased and they were closely spaced within the cells, either as clumps (Pl. 3, fig. 49) or singly in the cells (Pl. 3, fig. 52). The clumping of the inclusions in masses or as closely adjacent bodies increased the difficulties of observation. Even when the inclusions appeared as discrete bodies (PI. 3, fig. 53) it was often difficult to show the discrete form of the dark and brightly refractile inclusions as the edges of the two bodies often appeared to merge in the photographs. This was especially true of phase-contrast photographs (Pl. 3, fig. 50a); darkfield photographs, however, showed these bodies to be discrete (Pl. 3, fig. $50 \mathrm{~b}$ ).

The correlation between the living and fixed images of the chromatin bodies of Spirillum anulus, which was present during the preceding growth phase $(18-24 \mathrm{hr}$.$) , was not so apparent at this time (30-48 \mathrm{hr}$.). No structures resembling the axial filaments or chromatin aggregations of the acid-Giemsa cells ( $\mathrm{Pl}$. 3, figs. 39-44) were observed in the living cells. Certain formations, however, were observed in the living cells which could have possibly given rise to the formations in the acid-Giemsa cells. The clumps of inclusions shown in Pl. 3, figs. 49, $50 a, b$, could have given rise to the chromatin aggregations and the closely spaced inclusions, shown in $\mathrm{Pl}$. 3, figs. 51 $a, b, 52$, could have given rise to the axial filaments.

To explain the formation of the chromatin aggregations and axial filaments from these formations of the inclusions of the living cells, however, certain assumptions, which have not been verified experimentally, would have to be made. One such assumption is that the inclusions are hollow spheres which contain a material other than chromatin which is removed by acid hydrolysis, causing the collapse of the walls of the hollow sphere. This collapse might, conceivably, give the ring-like formations which are observed in the acidGiemsa cells. The brightly refractile centres of some of the inclusions of the living cells make this postulated structure feasible. Some corroboration for the hollow sphere structure is found in an ultrathin section of another species, 
Spirillum serpens, by Chapman \& Kroll (1957). Their fig. 8 shows a cell which contains two large vacuoles, the upper of which shows a smaller sphere of electron dense material. On the other hand, if the inclusions are, in reality, disk-shaped, as postulated by Robinow (1956 $a$ ) for similar ring-like formations in acid-Giemsa cells of Bacillus megaterium and $\boldsymbol{B}$. cereus, the entire spherical body would have to be enclosed in a delicate membrane which is destroyed by acid hydrolysis. The premise of a membrane surrounding the inclusions is based on the findings that the unhydrolysed inclusions appear as spherical bodies (Pl. 2, fig. 28) and the necessity of such a membrane to retain the material removed by acid hydrolysis at the centre of the inclusions.

Williams (1955), in an attempt to explain the staining peculiarities of these large inclusions, has postulated that they are composites of ribose- and deoxyribose nucleic acids. This is especially true since volutin has been considered to be a type of ribose nucleic acid by Meyer (1904), Casperson \& Brand (1941) and van den Berghe (1942). Knaysi (1951) states that volutin is removed from bacterial cells by acid hydrolysis and the removal of this substance from either the hollow spheres or the disk forms could account for the ring-like appearance of the inclusions ( $\mathrm{Pl}$. 2, fig. 26b). The massing of the inclusions in the cells during the growth cycle between the 30 th and $48 \mathrm{th} \mathrm{hr}$. would then account for the appearance of the chromatin aggregations and the axial filaments. As was pointed out above, both the structure and the supposed arrangements which could give rise to the formations in the acid-Giemsa cells are purely speculative. One contra-indication for this supposed type of structure of the inclusions is the data of Jacobson \& Webb (1952) in regard to the staining reactions of DNA and RNA in Giemsa-stained cells. These authors state that DNA alone appeared a shade of purple-red and that composites of DNA and RNA have a blue-black appearance in the chromosomes of bone marrow cells. The colour of the hydrolysed chromatin bodies in cells of Spirillum anulus is a bright red shade; that of the unhydrolysed chromatin bodies is a dark purple when stained with Giemsa.

Another possibility has been suggested by Robinow (1956 b), after a consideration of the data of Mudd \& Smith (1950) that hydrolysed chromatin bodies of bacterial cells have a greater electron density than unhydrolysed ones. Robinow has suggested 'the disquieting possibility that hydrolysis may cause material to shift from the cytoplasm to the nuclei.' It is possible that this shift of material from the cytoplasm to the chromatin bodies of Spirillum anulus may be the cause of the appearance of the axial filaments and chromatin aggregation. If so, this material cannot be RNA since the staining reaction of these bodies in the hydrolysed cells is a bright shade of red and not blue-black.

\section{DISCUSSION}

Robinow (1956b) has divided the chromatin bodies of bacteria into two categories-single solid shapes and open complex ones, which are described as follows: '...The solid shapes are straight or tapering bars or dumb-bells, the open ones are clusters of three or four, probably connected, round 
granules of the same size as the halves of the dumb-bells with one end nearly doubled, V-forms, paired dumb-bells, $\mathrm{H}$ - and butterfly shapes.' Some of the chromatin configurations which occur in acid-Giemsa cells of Spirillum anulus conform to this description by Robinow (Pl. 1, figs. 13, 14; Pl. 2, figs. 19-33). Robinow $(1956 a, b)$ has expounded on these particular types of chromatin bodies in bacteria and further comment would be superfluous. The other types of chromatin configurations found in acid-Giemsa cells of Spirillum anulus may be considered to be the type called 'axial filaments or cords' by Delaporte $(1939,1950)$ and compact aggregates by Whitfield \& Murray (1954, 1956).

These particular types of chromatin configurations have been demonstrated in cells of many bacterial species by numerous investigators (Delaporte, 1939, 1950; Bisset, 1956; Whitfield \& Murray, 1954, 1956). Two theories are current in regard to the occurrence of these axial filaments and chromatin aggregations. The one adopted by Delaporte $(1939,1950)$ and Bisset $(1956)$ is that such configurations occur normally in bacterial cells at some time during the growth cycle. The other theory is that such configurations are a response to abnormal conditions of growth in which the metabolism of the cell is disrupted by a variety of causes. Some of the conditions under which axial filaments or chromatin aggregations have been found in bacterial cells are: (1) ageing of the cells (Kellenberger, 1953); and (2) a response to conditions deleterious to cell growth and metabolism such as exposure to bacteriophages (Whitfield \& Murray, 1954), antibiotics (DeLamater, 1953; Kellenberger, 1953), high salt concentrations (Whitfield \& Murray, 1956), low temperatures (HunterSzybalska, Szybalski \& DeLamater, 1956), ultraviolet irradiation (Hartman, Payne \& Mudd, 1955) as well as to other causes.

Whitfield \& Murray $(1954,1956)$ have recently investigated the occurrence of such axial filaments and chromatin aggregations in a variety of bacterial species and have reached the conclusion that such formations are the result of an ionic imbalance within the cells due to external conditions. The experimental conditions cited by Whitfield \& Murray $(1954,1956)$ are incontrovertible. The explanation advanced by these authors, however, does not appear to fit the data found for cells of Spirillum anulus under the experimental conditions cited. External conditions deleterious to growth and metabolism were not imposed. These formations were found in cells of $S$. anulus taken from cultures grown under normal conditions of medium and temperature. These forms occur in very young cultures $(12 \mathrm{hr}$.), during the logarithmic growth phase (36-40 hr.) as well as in ageing cells (96-120 hr.). Exhaustion of nutrients in the broth medium can also be ruled out as a precipitating cause since they were found in cells which had been centrifuged and plated out on freshly poured agar plates and allowed to grow for at least $2 \mathrm{hr}$. before use. Whitfield \& Murray (1956) have shown that such aggregations, caused by conditions deleterious to growth and metabolism, were dispersed when cells of various bacterial species, grown under abnormal conditions, were transferred to fresh normal media. Both the axial filaments and chromatin aggregations were repeated in the cells at specific time intervals and other types of 
configurations often intervened between the times when these forms were found.

The theory that an ionic imbalance is the cause of the aggregations of the chromatin material in the cells is less easy to refute. It appears doubtful, however, that the normal medium, in which maximum growth occurred, could be the source of an ionic imbalance within the cells. If such be the case, then the cells of Spirillum anulus differ drastically from other bacterial cells since the majority of the cells, at a particular time interval, showed these formations. If the medium was the source of the ionic imbalance then the same medium which precipitated the imbalance also allowed the recovery of the cells, since these forms were always followed by the bars and bead-like granules considered the normal form of chromatin bodies in bacterial cells. Cessation of growth may also be eliminated as the precipitating cause of the axial filaments and chromatin aggregations since the greatest proportion of dividing cells were observed in the living cells during the time when these configurations were the most obvious $(30-44 \mathrm{hr}$.). These objections do not preclude the experimental data of Whitfield \& Murray (1954, 1956); rather they call for another explanation of these phenomena.

Bisset (1956, p. 8) considers such chromatin aggregations to be compound structures similar to the meganucleus of some of the protista and compares the two types of structures as follows: '...The comparable condition in bacteria I believe to be the longitudinal rod ( $\mathrm{Pl}$. 1, fig. 6) which occurs in the later stages of vegetative cultures of many types of bacteria.... And the most probable explanation is that it resembles the protozoan meganucleus in being not one but many nuclei, produced by repeated nuclear divisions in anticipation of cell division.'

Compound nuclear components are not unknown in higher organisms, the best known example probably being that of Ascaris megalocephala bivalens, in whose gametic cells two rod-shaped chromosomes are found. Walton (1924) has shown that these two rod-shaped chromosomes break up into approximately 22 small chromosomes for the autosomes and 8 for the sex chromosomes in the somatic cells of this organism.

One explanation for the occurrence of such aggregations of the chromatin material in bacterial cells, when exposed to conditions deleterious to growth and metabolism, has not been considered. If such aggregations represent a normal procedure of the chromatin material, involved in some process of cell preservation, the exposure of bacterial cells to conditions inimical to growth and metabolism would most probably invoke this protective mechanism and thus aid in conserving the cells.

Delaporte $(1939,1950)$ showed axial filaments and chromatin aggregations in bacterial cells and considered them to be a normal formation in rod-shaped bacteria. Bisset (1956) considered them to be compound structures and has devised a scheme by which these compound structures function as an autogamous process. The data found for cells of Spirillum anulus confirm and support the theory of Delaporte $(1939,1950)$; the data neither confirm nor refute the theory of Bisset (1956). 
I wish to acknowledge my indebtedness to Dr T. T. Chen, Department of Biology, for many helpful suggestions in regard to cytological procedures and for the stimulating discussions of the findings. I wish to express my appreciation of the technical assistance of Mr Richard Fred.

\section{REFERENCES}

Badian, J. (1933). Eine cytologische Untersuchung über das Chromatin und den Entwicklungszyklus der Bakterien. Arch. Microbiol. 4, 490.

Berghe, L. van DEN (1942). Sur la presence d'acide pentose-nucléique sous forme grains de 'volutine' dans les trypanosomes. Acta biol. belg. 2, 464.

BISsET, K. A. (1956). Cellular organization in bacteria. Symp. Soc. gen. Microbiol. $6,1$.

Casperson, T. \& Brand, K. (1941). Nucleotidumsatz and Wachstum bei Presshefe. Protoplasma, 35, 50\%.

Chapman, G. B. \& Kroll, A. J. (1957). Electron microscopy of ultrathin sections of Spirillum serpens. J. Bact. 73, 63.

Cumfton, C. E. \& EhrHard, H. H. (1952). Nuclear changes in living cells of a variant of Bacillus anthracis. J. Bact. 63, 537.

DeLamater, E. D. (1953). Structure and division of the bacterial nucleus. Bacterial Cytology, Symp. 6th Congr. Int. Microbiol. Rome, p. 108.

Delaporte, B. (1939). Recherches cytologiques sur les Bactéries et les Cyanophycées. Rev. gen. Bot. 51, 615, 689, 748.

Delapore, B. (1950). Observations on the cytology of bacteria. Advanc. Genet. $3,1$.

Dobell, C. C. (1911). Contributions to the cytology of the bacteria. Quart. J. micr. Sci. 56, 395.

Grimme, A. (1902). Die wichtigsten Methoden der Bakterienfärbung in ihrer Wirkung auf die Membran der Protoplasten und die Einschlüsse der Bakterienzelle. Zbl. Bakt. (Abt. I. Orig.), 32, 81, 161, 241.

Gunlliermond, A. (1908). Contribution à l'étude cytologique des bacilles endospores. Arch. Protistenk. 12, 9.

Hartman, P. E., Payne, J. \& Mudd, S. (1955). Cytological analysis of ultraviolet irradiated Escherichia coli. J. Bact. 70, 531.

Hunter-Szybalska, M. E., Szybalski, W. \& Delamater, E. D. (1956). Temperature synchronization of nuclear and cellular division in Bacillus megaterium. J. Bact. 71, 17.

$J_{\text {ACoBson, }}$ W. \& WeBB, M. (1952). The two types of nucleoproteins during mitosis. Exp. Cell Res. 3, 163.

KeLLeNberger, E. (1953). Les formes caractéristiques des nucléoides de $\boldsymbol{E}$. coli et leurs transformation dues à l'action d'agents mutagènes-inducteurs et bactériophages. Bacterial Cytology, Symp. 6th Congr. Int. Microbiol. Rome, p. 45.

KNAYSI, G. (1951). Elements of Bacterial Cytology, 2nd ed. Ithaca, New York: Comstock Publishing Co.

Mason, D. J. \& Powerson, D. (1956). Nuclear division as observed in live bacteria by a new technique. J. Bact. 71, 474 .

MEYER, A. (1904). Orientierende Untersuchungen über Verbreitung, Morphologie und Chemie des Volutin. Bot. Ztg, 62, 113.

Mirler, T. H. \& Brummitr, W. (1945). This is Photography, 1st ed. Garden City, N.Y.: Garden City Publishing Co.

MUdD, S. \& SMITH, A. G. (1950). Adaptation of cytological processing to electron microscopy ; bacterial nuclei as vesicular structures. J. Bact. 59, 561 .

Murray, R. G. E. (1953). The problem of fixation for studies of bacterial nuclei. Bacterial Cytology, Symp. 6th Congr. Int. Microbiol. Rome, p. 136. 
Journal of General Microbiology, Vol. 21, No. 1

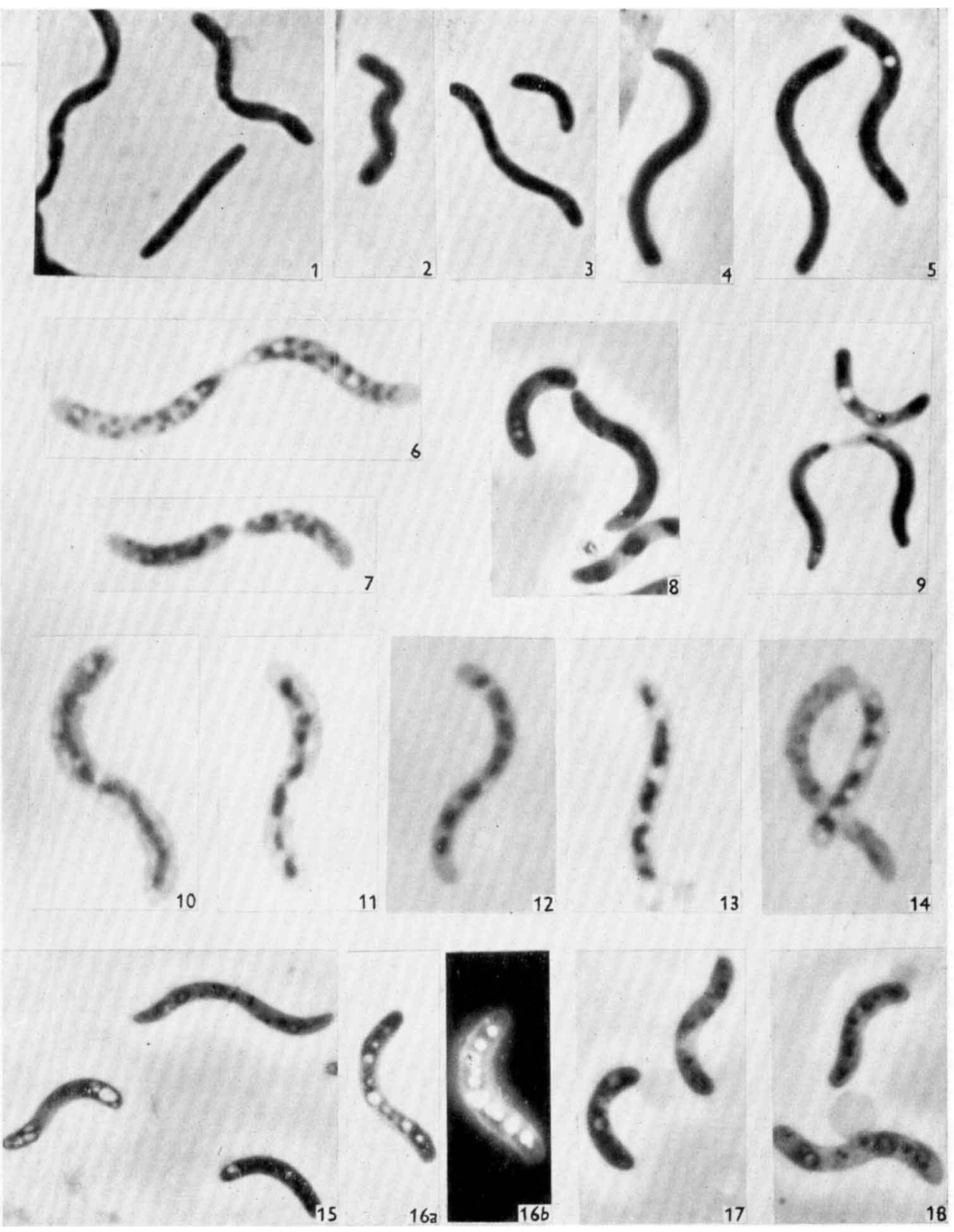

M. A. Williams-Chromatin pattenns in S. anUlus. Plate 1 
Journal of General Microbiology, Vol. 21, No. 1

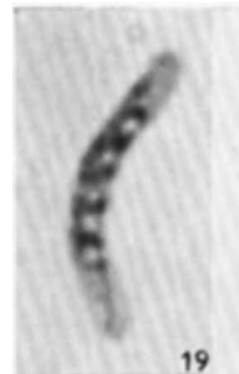

19
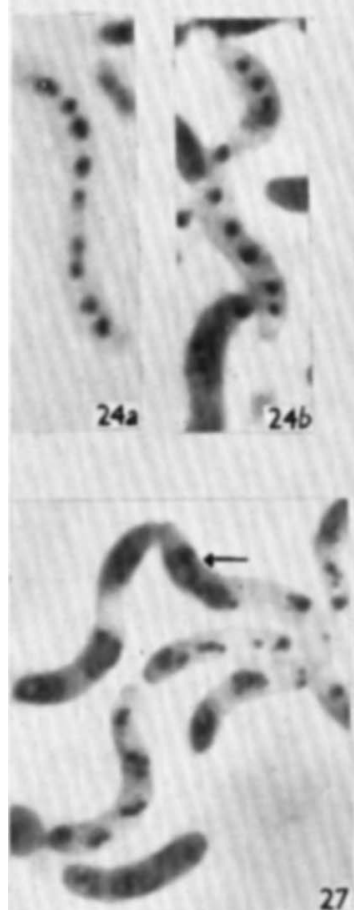

27

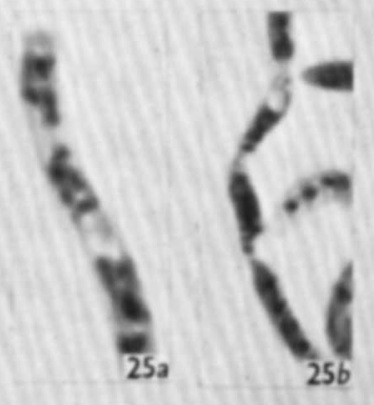

20

21
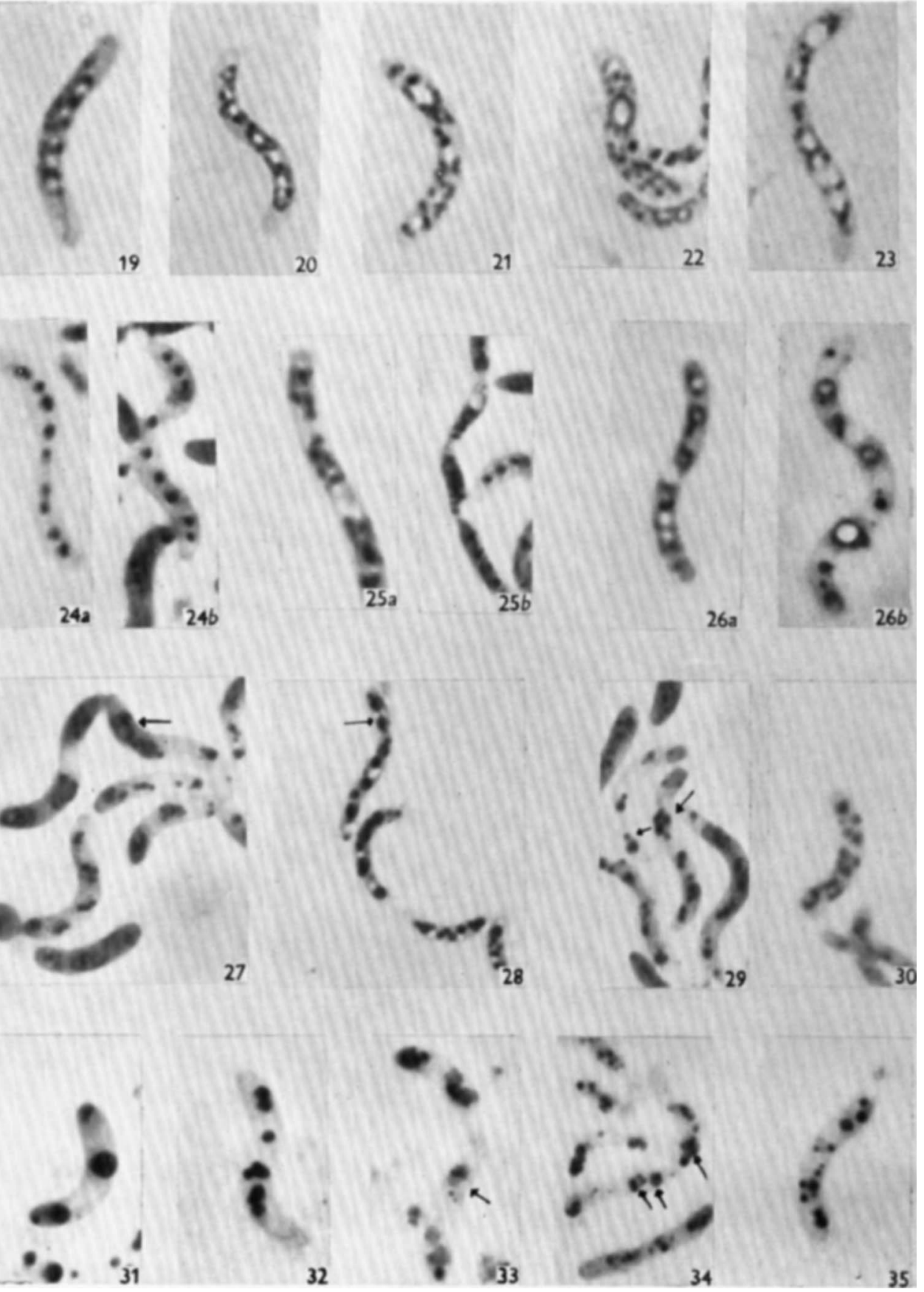

M. A. Williams-Chromatin patterns in S. anulus. Plate 2 
Journal of General Microbiology, Vol. 21, No. 1

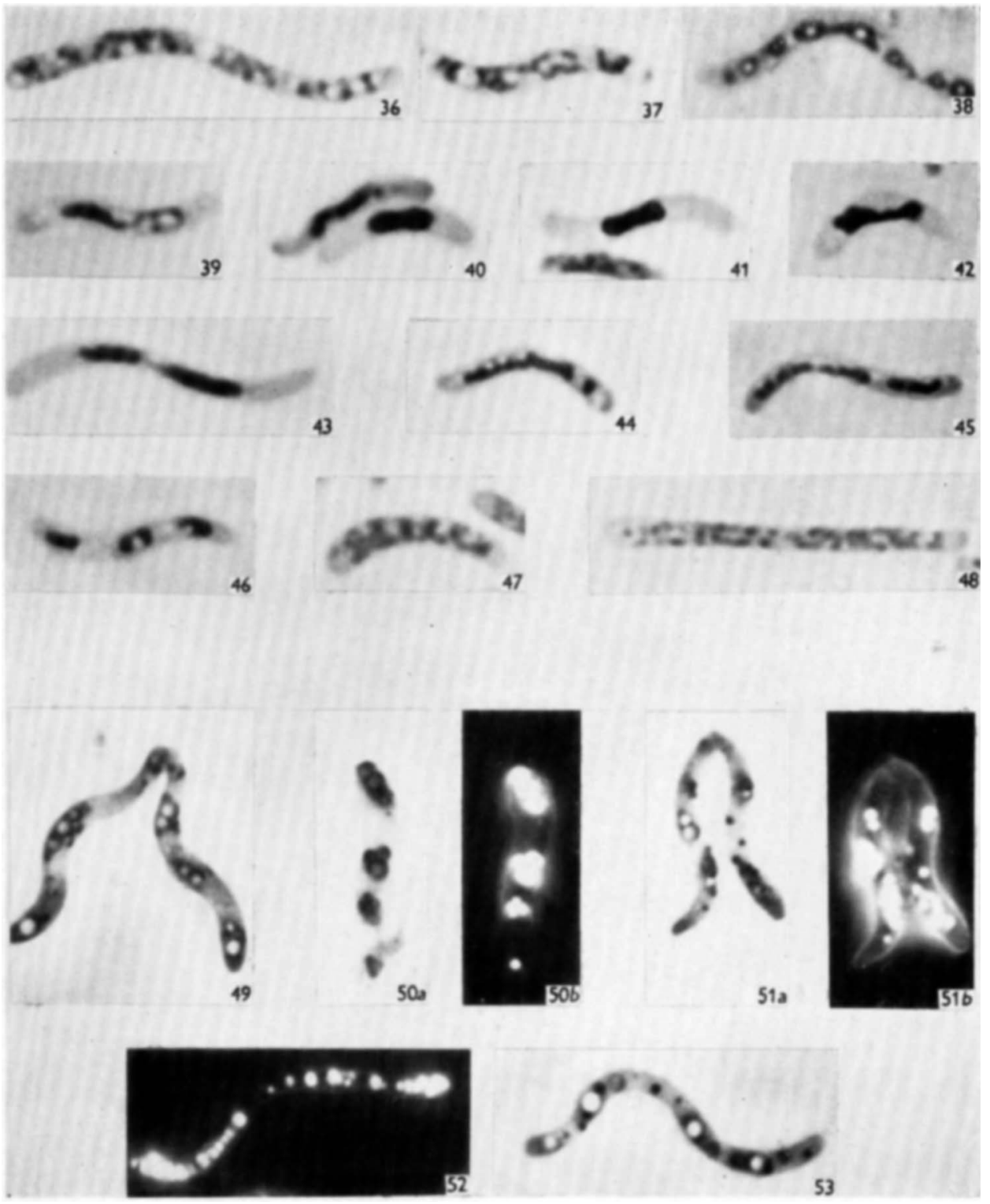

M. A. IVilliams-Chromatin patterns in S. anUlus. Plate 3 
Rosinow, C. F. (1944). Cytological observations on Bact. coli, Proteus vulgaris and various aerobic spore-forming bacteria with special reference to the nuclear structure. J. Hyg., Camb. 43, 413.

Rosinow, C. F. $(1956 a)$. The chromatin bodies of bacteria. Symp. Soc. gen. Microbiol. 6, 181.

Rosinow, C. F. (1956b). The chromatin bodies of bacteria. Bact. Rev. 20, 207.

STEMPEN, H. (1950). Demonstration of the chromatinic bodies of Escherichia coli and Proteus vulgaris with the aid of the phase contrast microscope. J. Bact. 60, 81.

StrLle, B. (1937). Zytologische Untersuchungen an Bakterien mit Hilfe der Feulgenschen Nuclear reaktion. Arch. Mikrobiol. 8, 125.

Walton, A. C. (1924). Studies on nematode gametogenesis. Z. Zell.- u. Gervebelehre, $1,167$.

Whitfield, J. F. \& Murray, R. G. E. (1954). A cytological study of the lysogenation of Shigella dysenteriae with $\mathrm{P}_{1}$ and $\mathrm{P}_{2}$ bacteriophages. Canad. J. gen. Microbiol. 1, 216.

Whitfield, J. F. \& Murray, R. G. E. (1956). The effects of the ionic environment on the chromatin structures of bacteria. Canad. J. gen. Microbiol. 2, 245.

Willuams, M. A. (1955). Staining reactions of granules of spirilla species. Bact. Proc. p. 34.

Williams, M. A. \& Rittenberg, S. C. (1957). A taxonomic study of the genus Spirillum Ehrenberg. Int. Bull. bact. Nomen. Taxon. 7, 49.

\section{EXPLANATION OF PLATES}

All photographs are of Spirillum anulus

\section{Plate 1}

Figs. 1-3. Acid-Giemsa cells from 10,4 and $8 \mathrm{hr}$. cultures, respectively, showing undifferentiated appearance of cells despite $15 \mathrm{~min}$. of acid hydrolysis. $\times 3200$.

Figs. 4, 5. Phase-contrast photographs of living cells from 10 and $12 \mathrm{hr}$. cultures, respectively, showing undifferentiated appearance of early cells. $\times 3200$.

Figs. 6, 7. Acid-Giemsa cells from 48 and $30 \mathrm{hr}$. cultures, respectively, showing cell division and the $\frac{1}{2}$ and $1 \frac{1}{2}$ curved forms of the division cells. $\times 3600$.

Figs. 8, 9. Phase-contrast photographs of living cells from 16 and $14 \mathrm{hr}$. cultures, respectively, showing cell division and the $\frac{1}{2}$ and $1 \frac{1}{2}$ curved forms of the dividing cells. $\times 3600$.

Figs. 10-14 are all of acid-Giemsa cells

Fig. 10. Cell from $12 \mathrm{hr}$. culture showing axial filament of chromatin material and dark staining of the cytoplasm. $\times 4000$.

Fig. 11. Cell from $14 \mathrm{hr}$. culture showing fragmentation of the axial filament into thick bars. $\times 4000$.

Fig. 12. Cell from $16 \mathrm{hr}$. culture showing spherical forms of the chromatin material. $\times 4000$.

Fig. 13. Cell from $16 \mathrm{hr}$. culture showing curved bar-like forms originating from spherical bodies. $\times 4000$.

Fig. 14. Cells from $16 \mathrm{hr}$. culture showing division of spherical bodies as well as cell division. $\times 4000$.

Figs. 15-18 are all of living cells

Fig. 15. Phase-contrast photograph of cells from $14 \mathrm{hr}$. culture showing appearance of the inclusions in the cells; the cytoplasm remains dark. $\times 3600$.

Fig. 16 $a, b$, Phase-contrast and darkfield photographs of the same cell from a $16 \mathrm{hr}$. culture showing the appearance of the inclusions as empty vacuoles in the phase-contrast photograph $(16 a)$ and their appearance as solid spherical bodies by darkfield. Notice that it is not possible to differentiate the periphery of the inclusions from the dark cytoplasm in the phase contrast photograph. $\times 3600$. 
Figs. 17, 18. Phase-contrast photographs of cells from an $18 \mathrm{hr}$. culture showing the inclusions and the lighter cytoplasm of the cells at this time interval. The inclusions appear as dark spheres and as rings of dark material enclosing a lighter material. $\times 3600$.

\section{Plate 2}

Figs. 19-23 are of acid-Giemsa cells

Fig. 19. Cell from $18 \mathrm{hr}$, culture showing horizontal bar-like chromatin material. $\times 4000$.

Fig. 20. Cell from $20 \mathrm{hr}$. culture showing separation of horizontal bars into V-forms. $\times 4000$.

Fig. 21. Cell from $22 \mathrm{hr}$. culture showing chromatin material as a broken ring, which may indicate method of division of this chromatin configuration. Intermediate $\mathbf{X}-, \mathbf{Y}_{-}$, and $V$-forms are seen in the lower part of cell. $\times 4000$.

Fig. 22. Cell from $24 \mathrm{hr}$. culture showing two rings of chromatin material, surrounding an achromatic core. Small interconnected bead-like granules are seen in the lower part of cell. $\times 4000$.

Fig. 23. Cell from $26 \mathrm{hr}$. culture showing several ring-like forms, surrounding an achromatic core. Possible division forms are seen in several of these chromatin structures. $\times 4000$.

Figs. 24 $a, b$. Acid Giemsa and living cell photographed by phase contrast, respectively, showing an exact correlation between the fixed and living images of the chromatin bodies. From an $18 \mathrm{hr}$. culture. $\times 3600$.

Figs. 25 $a, b$. Acid-Giemsa and living cell photographed by phase contrast, from an $18 \mathrm{hr}$. culture, showing the correlation between the horizontal bar-like forms. $\times 3600$.

Fig. 26a. Acid-Giemsa cell from $26 \mathrm{hr}$. culture showing ring forms. $\times 3600$.

Fig. 26b. Living cell photographed by phase contrast showing apparent correlation between the same forms of ring-like bodies in living cells. (See text for a discussion of the visual appearance of the large ring-like inclusions.) Small inclusions show apparent budding. $\times \mathbf{3 6 0 0}$.

Fig. 27. Living cells, photographed by phase contrast, from a $24 \mathrm{hr}$. culture showing ringlike forms in upper cell (marked with an arrow) and small bead-like granules in lower cells. $\times 3600$.

Fig. 28. Fixed, Giemsa-stained but unhydrolysed cells from same $24 \mathrm{hr}$. culture as cells in fig. 27, showing spherical form of large ring-like inclusions (upper cell, marked with an arrow) and the correlation between the small bead-like granules of the living cell. $\times 3600$.

Fig. 29. Phase-contrast photograph of cells from $24 \mathrm{hr}$. culture showing ring-like form of bead-like granules (marked with an arrow in 2nd cell from right) as well as budding (marked with an arrow in 2 nd cell from left). $\times 3600$.

Fig. 30. Acid-Giemsa cell from 24 hr. culture showing ring formation of bead-like granules as well as discrete granules. $\times \mathbf{3 6 0 0}$.

Figs. 31-35. Phase-contrast photographs of living cells

Fig. 31. Cell from a $20 \mathrm{hr}$. culture showing large spherical inclusions. $\times 3600$.

Fig. 32. Cell from $22 \mathrm{hr}$. culture showing division of large spherical inclusions (upper inclusion); the subdivision of the small inclusions into more than one body (middle inclusions) and the formation of the semicireular bodies from the inclusions. $\times 3600$.

Fig. 33. Cell from $22 \mathrm{hr}$. culture showing semicircular forms with budding of small beadlike granules from inclusions marked with an arrow. $\times 3600$.

Fig. 34. Cells from $24 \mathrm{hr}$. culture showing formation of rings of bead-like granules from spherical inclusions (marked with arrows). $\times 3200$.

Fig. 35. Cell from $26 \mathrm{hr}$. culture showing spherical inclusions (upper part of cell) and formation of $\mathrm{V}$-forms from these bodies. $\times \mathbf{3 6 0 0}$.

Plate 3

Figs. 36-48 are of acid-Giemsa cells

Figs. 36. Cells from $30 \mathrm{hr}$. culture showing condensation of bead-like granules into bars. Cell division is occurring at the centre. $\times 4000$.

Fig. 37. Cell from $32 \mathrm{hr}$. culture showing aggregation of chromatin material at edges of vacuoles. $\times \mathbf{4 0 0 0}$. 
Fig. 38. Cell from $34 \mathrm{hr}$. culture showing a series of connected rings of chromatin material. $\times 4000$.

Fig. 39. Cell from $38 \mathrm{hr}$. culture, showing aggregation of chromatin material into an axial filament, around the vacuoles of the cell. $\times 4000$.

Figs. 40-41. Cells from $40 \mathrm{hr}$. culture showing compact arrangement of chromatin material at centre of the cells in the form of a solidly staining mass. $\times 4000$.

Fig. 42. Cell from $42 \mathrm{hr}$. culture showing division of chromatin aggregation. $\times 4000$.

Fig. 43. Cell from $42 \mathrm{hr}$. culture showing division of chromatin mass coinciding with cell division. $\times 4000$.

Fig. 44. Cell from $42 \mathrm{hr}$. culture showing extension of chromatin material, along the vacuoles of the cells, of the compact chromatin mass. $\times \mathbf{3 6 0 0}$.

Fig. 45. Cell from $44 \mathrm{hr}$. culture showing formation of spherical bodies and curved bars from the axial filament of chromatin material. $\times 3600$.

Fig. 46. Cell from $44 \mathrm{hr}$. culture showing division of chromatin bars. $\times 4000$.

Fig. 47. Cell from $46 \mathrm{hr}$, culture showing horizontal bars. $\times 4000$.

Fig. 48. Cell from $48 \mathrm{hr}$. culture showing rings and chains of bead-like granules. $\times 4000$.

Figs. 49-52. Living cells photographed by phase contrast and darkfield microscopy.

Fig. 49. Cell from $38 \mathrm{hr}$. culture showing clusters of inclusions as well as difficulty in differentiating the individual inclusions. These clusters may give rise to the compact chromatin aggregations of the acid-Giemsa cells. $\times 3600$.

Figs. 50a, b. Phase-contrast and darkfield photographs of the same cells from a $36 \mathrm{hr}$. culture, showing elusters of inclusions; the difficulty of differentiating the inclusions in the phase-contrast photograph $(50 a)$ which appear to merge. The discreteness of the inclusions is shown in the darkfield photograph $(50 \mathrm{~b}) . \times 3600$.

Fig. 51 $a, b$. Phase-contrast and darkfield photographs of the same cells from a $30 \mathrm{hr}$. culture showing arrangement of inclusions which might give rise to the axial filaments in the acid-Giemsa cells. Merging of the inclusions in lower cells is shown in phase-contrast photograph $(51 a)$ but darkfield photograph $(51 b)$ shows these bodies to be discrete. $\times 3600$.

Fig. 52. Darkfield photograph of cell from $32 \mathrm{hr}$. culture showing close spacing of inclusions which might give rise to the appearance of an axial filament in the acid-Giemsa cells. $\times 3600$.

Fig. 53. Phase-contrast photograph of cell from $30 \mathrm{hr}$. culture showing discrete arrangement of inclusions and obvious photographic differences in the type of inclusions. The two spherical dark inclusions, at either side of the brightly refractile inclusion at right of cell, appear to merge with this body. $\times 3600$.

(Received 8 December 1958) 